\title{
Solitary fibrous tumor of the pleura - analysis of 18 cases
}

\author{
Bartosz Cieślik-Wolski ${ }^{1}$, Łukasz Pryt ${ }^{1}$, Aleksandra Szlachcińska ${ }^{1}$, Grażyna Walczak-Pasz ${ }^{2}$, \\ Dorota Jesionek-Kupnicka², Józef Kozak ${ }^{1}$ \\ ${ }^{1}$ Department of Thoracic Surgery and Respiratory Rehabilitation, Medical University of Lodz, Poland \\ ${ }^{2}$ Department of Pathology, Copernicus Memorial Hospital in Lodz, Poland
}

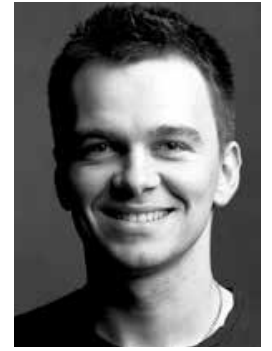

Kardiochirurgia i Torakochirurgia Polska 2015; 12 (3): 208-215

\begin{abstract}
Introduction: Solitary fibrous tumors of the pleura (SFTP) are primary tumors arising from mesenchymal cells. Immunohistochemical studies have demonstrated that the origin of these tumors is mesenchymal rather than mesothelial. The aim of this study is to present our experience with diagnosing and treating patients with SFTP.

Material and methods: We analyzed 18 patients treated at the Department of Thoracic Surgery of the Medical University of Lodz. The patients' medical histories and the results of postoperative histopathological investigation of the tumors were analyzed. Postoperative histopathological samples were evaluated with regard to the current criteria of malignancy.

Results: In 17 patients, the tumors were surgically removed. Benign and small lesions (less than $3 \mathrm{~cm}$ in size) were removed by video-assisted thoracoscopic surgery (VATS). In 5 cases, malignant tumors were found in the postoperative material. Conclusions: Solitary fibrous tumors of the pleura is a tumor with frequently asymptomatic clinical course. Treatment consists in resection which includes the adjacent structures, especially if the tumor is malignant.
\end{abstract}

Key words: solitary fibrous tumor, pleural tumors, VATS.

\section{Introduction}

Primary tumors of the pleura exist as diffuse or localized. Diffuse ones, mainly mesotheliomas, derive from mesothelial cells lining the pleural cavity. They are usually more malignant, and their occurrence is often associated with exposure to asbestos. A less frequent and localized type of pleural tumor is solitary fibrous tumor of the pleura (SFTP) originating from the subepithelial mesenchymal

\section{Streszczenie}

Wstęp: Izolowany guz włóknisty opłucnej (solitary fibrous tumors of the pleura-SFTP) jest rzadkim guzem pierwotnym wywodzącym się z komórek mezenchymalnych tkanki łącznej. Badania immunohistochemiczne potwierdziły, że nowotwór ten nie ma związku z międzybłoniakiem opłucnej - najczęstszym guzem pierwotnym opłucnej. Celem pracy było przedstawienie doświadczenia własnego w diagnozowaniu i leczeniu SFTP. Materiał i metody: Analizie poddano 18 pacjentów leczonych na Oddziale Chirurgii Klatki Piersiowej UM w Łodzi w latach 1998-2014. Przeanalizowano historię chorób pacjentów oraz wyniki pooperacyjnych badań histopatologicznych resekowanych guzów. Pooperacyjny materiał poddano ocenie histopatologicznej z uwzględnieniem obowiązujących kryteriów złośliwości.

Wyniki: U 17 pacjentów (94\%) zmianę udało się usunąć. Zmiany łagodne i poniżej $3 \mathrm{~cm}$ usunięto metodą wideotorakoskopową (video-assisted thoracoscopic surgery - VATS). W 5 przypadkach stwierdzono cechy złośliwości w przebadanym materiale pooperacyjnym.

Wnioski: Izolowany guz włóknisty opłucnej to rzadki, zazwyczaj łagodny guz o często bezobjawowym przebiegu klinicznym. Leczenie polega na całkowitej resekcji guza, w tym struktur sąsiednich, jeśli zmiana ma charakter złośliwy.

Słowa kluczowe: izolowany guz włóknisty, guzy opłucnej, wideotorakoskopia.

layer. Such lesions are usually benign: only about $20 \%$ are malignant [1-4]. In past years, the origin of this tumor gave rise to much controversy. It was previously known as benign or localized fibrous mesothelioma, pleural fibroma, submesothelial fibroma, or localized fibrous tumor [3-5]. The progress that has been made in immunohistochemistry and electron microscopy led to the introduction of the name solitary fibrous tumor of the pleura to distinguish it from the more malignant mesothelioma [6, 7]. The first

Address for correspondence: Bartosz Cieślik-Wolski, Department of Thoracic Surgery and Respiratory Rehabilitation, Medical University of Lodz, 62 Pabianicka St., 93-513 Łódź, Poland, phone: +48 4268952 33, e-mail: bartoszcw@gmail.com 
mention of SFTP was made by Wagner in 1870 [8], but the first pathological description by Klemperer and Rabin was published only in 1931 [9]. A review of 223 cases of fibrous tumors of the pleura, detailing their histological features, was presented by England et al. in 1989. Scientists have discovered three histopathological criteria associated with the malignant nature of the tumor: a large number of cells with overlapping nuclei, increased mitotic activity, and nuclear pleomorphism [10].

The aim of this study is to present the experience of our department in the diagnosis and treatment of patients with benign and malignant solitary fibrous tumors of the pleura. The study highlights the possibility of using video-assisted thoracoscopic surgery (VATS) in the resection of benign and pedunculated SFTP originating from the pulmonary pleura.

\section{Material and methods}

The study included 18 patients ( 11 women and 7 men) treated for solitary fibrous tumors of the pleura from November 1998 to December 2014 at the Clinical Department of Thoracic Surgery and Rehabilitation, Medical University of Lodz, Copernicus Memorial Hospital. The patients' age ranged from 36 to 74 years (mean: 58.3 years). The analysis included the medical histories, the results of physical examinations, basic blood tests, imaging tests including $\mathrm{X}$-ray and chest computerized tomography (CT) scan, and the results of postoperative histopathological investiga- tion. On the basis of the descriptions of the performed surgical procedures, we specified the origin of the tumors (visceral or parietal pleura) and the presence or absence of pedicles. Microscopic preparations were reanalyzed to determine the nature of the changes. Histologically, the cases of SFTP were classified as benign or malignant in accordance with the criteria published by England et al. [10]. Malignant tumor was diagnosed when one or more of the following criteria were met:

- mitotic count of more than 4 mitoses per 10 high-power fields (HPF),

- the presence of necrosis or hemorrhage,

- hypercellularity with crowding and overlapping of nuclei,

- the presence of pleomorphism classified on the basis of nuclear size, irregularity, and nucleolar prominence.

According to the criteria published by Yokoi et al. [11], histological signs of malignancy include stromal or vascular invasion.

The results were based on the patients' follow-up documentation including $X$-ray imaging and chest CT.

\section{Results}

Over half of the patients (55\%) were asymptomatic, and the reason to seek medical advice was the finding of a pathological lesion in control chest X-ray. The clinical characteristics of the patients are presented in Table I. Symptoms such as periodic dyspnea, cough, or chest pain

Tab. I. Clinical characteristics of patients with solitary fibrous tumors of the pleura

\begin{tabular}{|c|c|c|c|c|c|c|c|}
\hline No & Age/Sex & Side & Symptoms & Size $(\mathrm{cm})$ & Diabetes & Cigarette smoking & Preoperative biopsy \\
\hline 1 & $49 / M$ & $\mathrm{R}$ & No & $6 \times 4$ & No & Yes & No \\
\hline 2 & $52 / \mathrm{W}$ & $L$ & No & $3 \times 3$ & No & No & No \\
\hline 3 & $52 / \mathrm{W}$ & L & No & $3 \times 2$ & No & Yes & No \\
\hline 4 & $65 / M$ & L & C, D, P, HPO, CF & $12 \times 10$ & Yes & Yes & Yes \\
\hline 5 & $58 / M$ & L & $\mathrm{C}, \mathrm{P}$ & $8 \times 5$ & No & Yes & Yes \\
\hline 6 & $36 / \mathrm{W}$ & $L$ & No & $2 \times 1$ & No & No & No \\
\hline 7 & $71 / \mathrm{W}$ & $\mathrm{R}$ & $C, P, D, H$ & $12 \times 10,8 \times 6,7 \times 5,7 \times 4$ & No & No & Yes \\
\hline 8 & $74 / \mathrm{W}$ & L & $P$ & $5 \times 5$ & No & No & No \\
\hline 9 & $74 / W$ & $R$ & No & $2 \times 2$ & No & Yes & No \\
\hline 10 & $62 / W$ & $\mathrm{~L}$ & No & $3 \times 2$ & Yes & Yes & No \\
\hline 11 & $64 / M$ & L & $P, C$ & $5 \times 4$ & Yes & No & No \\
\hline 12 & $45 / M$ & $\mathrm{~L}$ & No & $3 \times 2$ & No & Yes & No \\
\hline 13 & $51 / M$ & $R$ & C, P & $7 \times 5$ & No & Yes & Yes \\
\hline 14 & $66 / W$ & $R$ & $C$ & $4 \times 5$ & No & No & No \\
\hline 15 & $55 / W$ & $\mathrm{R}$ & No & $3 \times 3$ & No & No & No \\
\hline 16 & $67 / M$ & L & No & $3 \times 2$ & Yes & Yes & No \\
\hline 17 & $53 / \mathrm{W}$ & $\mathrm{L}$ & $C$ & $6 \times 5$ & No & No & No \\
\hline 18 & $70 / W$ & $\mathrm{R}$ & $P$ & $4 \times 2$ & Yes & No & No \\
\hline
\end{tabular}

C-cough, D - dyspnea, P - pain, CF - clubbed fingers, $\mathrm{H}$ - hypoglycemia, HPO - hypertrophic osteoarthropathy 


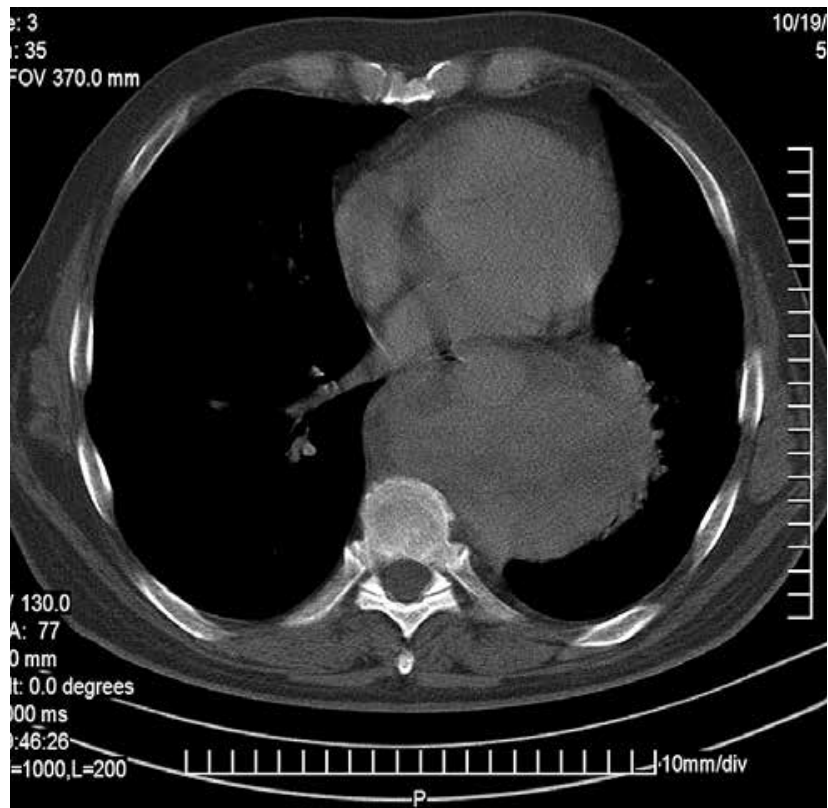

Fig. 1. Malignant solitary fibrous tumor of the pleura. An inoperable tumor invading mediastinal structures. Heterogeneous hemorrhagic and necrotic foci of the tumor

A
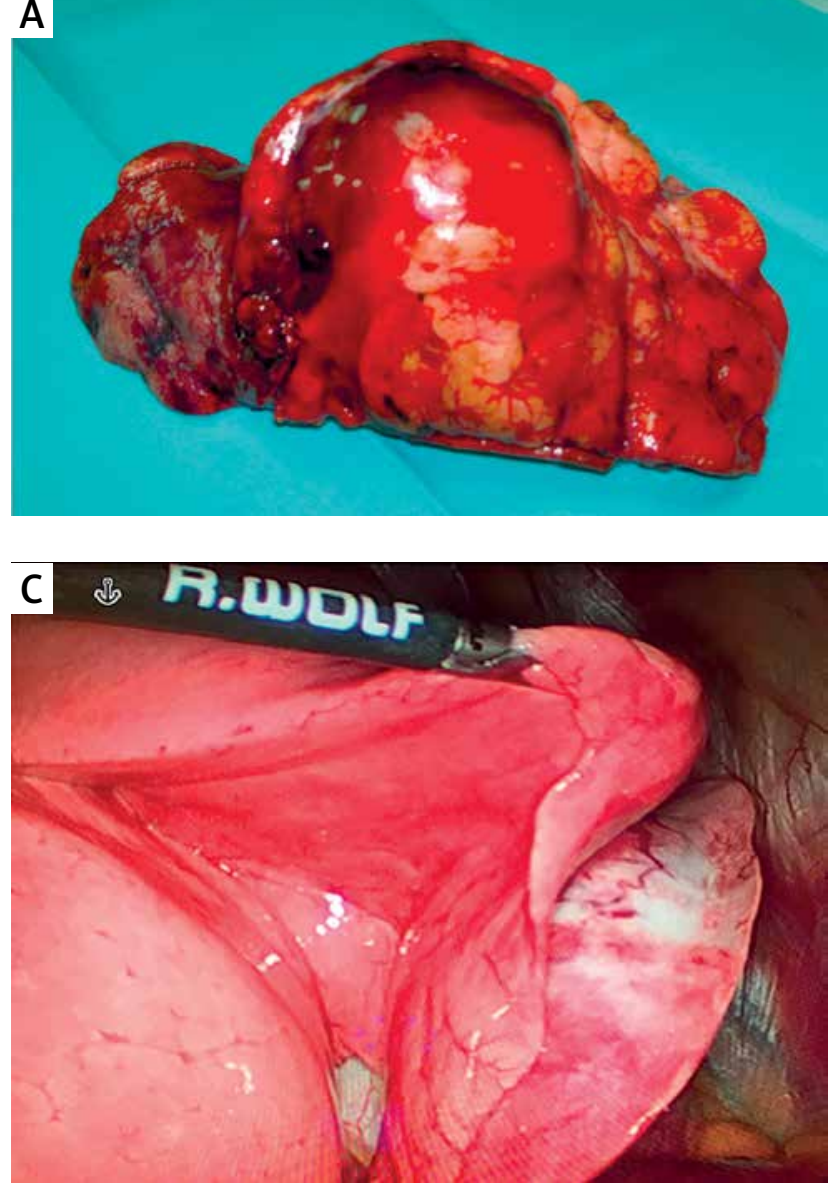

occurred in 4 patients with benign tumors (30\%) and in 4 with malignancy (80\%).

All patients underwent computed tomography of the chest, bronchofiberoscopy, and spirometry. In 4 cases, fineneedle aspiration biopsy was performed (in 3 patients, the biopsy was conducted under X-ray control, and in 1 blind biopsy was conducted during bronchofiberoscopy). Diagnosis was obtained only in 2 cases. In 17 patients (94\%), the tumor was successfully removed during surgery. In 1 patient with a tumor approximately $12 \mathrm{~cm}$ in diameter and infiltrating mediastinal structures including the aorta, the lesion was considered inoperable (Fig. 1).

In 5 cases (27\%), the tumors were successfully removed using the VATS method, and, in 1 case, it was necessary to convert to thoracotomy. Five patients (27\%) underwent anterolateral thoracotomy, 7 (38\%) mini-thoracotomy, and 1 (5\%) sternotomy. The pathological mass derived from the visceral pleura in 5 patients and from the parietal pleura in 11. In 6 cases (33\%), the tumors were pedunculated (Fig. 2). Multifocal pathology consisting of 4 separated capsulated tumors of large size (up to $12 \times 10 \mathrm{~cm}$ ) was found in 1 patient. Moreover, in another patient, fragments of 2 intercostal spaces were removed along with the tumor. The types of surgery and the

Fig. 2. Benign solitary fibrous tumors. A non-pedunculated tumor, size $7 \times 5 \mathrm{~cm}$, with lung tissue, originated from the pulmonary pleura: (A) post-operative specimen and (B) cross-section. A pedunculated tumor of the pleura: (C) thoracoscopic view and (D) post-operative specimen 
Tab. II. Type of surgery and characteristics of the postoperative specimens

\begin{tabular}{|c|c|c|c|c|}
\hline No. & Surgery & Type of resection & Pleura & Peduncle \\
\hline 1 & Minithoracotomy & Tumor resection & Visceral & No \\
\hline 2 & VATS & Tumor resection & Parietal & Yes \\
\hline 3 & $\begin{array}{c}\text { VATS/ } \\
\text { Minithoracotomy }\end{array}$ & Tumor resection & Parietal & No \\
\hline 4 & Thoracotomy & Exploratory outcome & Visceral & No \\
\hline 5 & Sternotomy & Tumor resection & Visceral & No \\
\hline 6 & VATS & Tumor resection & Visceral & Yes \\
\hline 7 & Thoracotomy & Lobectomy, chest wall resection & Parietal & No \\
\hline 8 & Minithoracotomy & Tumor resection & Parietal & No \\
\hline 9 & VATS & Tumor resection & Parietal & No \\
\hline 10 & Minithoracotomy & Tumor resection & Parietal & Yes \\
\hline 11 & Thoracotomy & Tumor resection & Parietal & Yes \\
\hline 12 & VATS & Tumor resection & Parietal & No \\
\hline 13 & Thoracotomy & Lobectomy & Parietal & No \\
\hline 14 & Minithoracotomy & Tumor resection & Parietal & No \\
\hline 15 & VATS & Tumor resection & Parietal & Yes \\
\hline 16 & Minithoracotomy & Tumor resection & Visceral & Yes \\
\hline 17 & Thoracotomy & Tumor resection & Parietal & No \\
\hline 18 & Minithoracotomy & Tumor resection & Parietal & No \\
\hline
\end{tabular}

macroscopic tumor characteristics are presented in Table II (histopathological characteristics of the tumors - see Table III).

Postoperative 30-day mortality was $0 \%$. The average ward stay was 5.2 days (4 to 9). The average time of pleural drainage was 3.4 days after VATS and 5.3 days after treatment with conventional opening of the chest.

According to the criteria published by England et al. and Yokoi et al., the histopathological hematoxylin and eosin stain material revealed malignancy in 5 cases (28\%). Immunohistochemical analysis showed positive expression of CD34 and vimentin and a negative relation to cytokeratin in all SFTP cases (Fig. 3 and 4).

All the patients were referred to the outpatient clinic for follow-up studies. The period of postoperative follow-up ranged from 4 to 212 months. There was no tumor recurrence in patients with benign tumors and in 4 patients with malignant ones. The patient who was found inoperable died after 5 months because of progression of the disease.

\section{Discussion}

Solitary fibrous tumors of the pleura are rare and are usually benign. The medical literature describes 900 cases of this tumor [12]. In lesions originating from the pleura, SFTP represent less than $10 \%$, while $90 \%$ are malignant mesotheliomas [13]. Authors from the Mayo Clinic described 60 cases during more than 25 years, which suggests an incidence of 3 cases per 100,000 admissions [14,
15]. Most modern studies of SFTP report that these tumors develop in 1-2 patients annually $[1,6,16]$.

Solitary fibrous tumors of the pleura derive from mesenchymal cells of the connective tissue underlying the epithelium covering the pleural cavities. Immunohistochemistry confirmed that this type of tumor can also be found in extrathoracic locations such as the meninges, nasal cavity, oral cavity, epiglottis, salivary glands, thyroid gland, mammary glands, kidneys, urinary bladder, and spinal cord [2-5].

Although the tumors may develop within a wide age range ( 5 to 87 years), they mainly occur in the $6^{\text {th }}$ and $7^{\text {th }}$ decades of life, with equal incidence in both sexes $[4,5,10]$.

There is no genetic predisposition to the disease, although familial occurrence in a mother and daughter was reported in one publication. There is also no relationship between the occurrence of these tumors and exposure to asbestos and cigarette smoking. Cytogenetic data on SFTP are heterogeneous and show different karyotype disorders. It has been suggested, however, that supernumerary chromosome 8 can increase the malignancy of the tumor $[3,17,18]$.

Many patients are asymptomatic and seek medical attention because of abnormal chest X-rays. The most common symptoms include chest pain, shortness of breath, and cough. Fever, night sweats, and weight loss are rare. The symptoms occur in $75-88 \%$ of patients with malignant tumors and in $42-67 \%$ of patients with benign tumors $[2-4,19]$. 
Tab. III. Histopathological characteristics of the tumors

\begin{tabular}{|c|c|c|c|c|c|c|c|}
\hline No. & $\begin{array}{l}\text { Mitotic count } \\
/ 10 \mathrm{HPF}\end{array}$ & Pleomorphism & Hypercellularity & Necrosis & $\begin{array}{l}\text { Stromal } \\
\text { invasion }\end{array}$ & $\begin{array}{l}\text { Vascular } \\
\text { invasion }\end{array}$ & Type of tumor \\
\hline 1 & 0 & - & - & - & - & - & Benign \\
\hline 2 & 0 & - & - & - & - & - & Benign \\
\hline 3 & 1 & - & - & - & - & - & Benign \\
\hline 4 & 1 & + & + & - & + & - & Malignant \\
\hline 5 & 5 & - & + & - & - & - & Malignant \\
\hline 6 & 0 & - & - & - & - & - & Benign \\
\hline 7 & 5 & + & + & + & + & + & Malignant \\
\hline 8 & 1 & - & - & - & - & - & Benign \\
\hline 9 & 0 & - & - & - & - & - & Benign \\
\hline 10 & 0 & - & - & - & - & - & Benign \\
\hline 11 & 6 & + & + & - & - & - & Malignant \\
\hline 12 & 0 & - & - & - & - & - & Benign \\
\hline 13 & 1 & - & - & - & - & - & Benign \\
\hline 14 & 1 & - & - & - & - & - & Benign \\
\hline 15 & 0 & - & - & - & - & - & Benign \\
\hline 16 & 0 & - & - & - & - & - & Benign \\
\hline 17 & 4 & - & - & + & + & - & Malignant \\
\hline 18 & 0 & - & - & - & - & - & Benign \\
\hline
\end{tabular}

The most common paraneoplastic syndrome, occurring mainly in patients with large tumors, is hypertrophic osteoarthropathy (HPO). Patients with HPO report flu-like symptoms, symptoms of arthritis, stiff neck, swelling of joints and ankles. The causes of HPO in SFTP patients are not well known. The symptoms resolve several days after tumor resection, suggesting that they are associated with short-term ectopic secretion of growth hormone [3-5, 10]. Clubbed fingers constitute the most common coexisting physical symptom in patients with HPO and SFTP. Clinically, the distal portions of the fingers are extended and enlarged with the characteristic relaxation of the nail bed. The etiology of the clubbing is not fully understood, but it is associated with the presence of arteriovenous anastomoses in the distal parts of the fingers along with periosteal new growth and lymphocytic and plasma cell infiltration of connective tissue in the nail beds [3]. In the group of patients admitted to our clinic, only 1 (5\%) had clubbed fingers and features of hypertrophic osteoarthropathy.

Hypoglycemia (Doege-Potter syndrome) is a rare manifestation of the disease $(<5 \%)$, caused by the secretion of tumor growth factors, e.g., insulin-like growth factor 2 (IGF-2). Hypoglycemia resolves after complete resection of the tumor [4-14, 16-20]. Periodical lower glucose levels (below $72 \mathrm{mg} / \mathrm{dl}$ ) were also observed in 1 of our patients.

Pleural effusion associated with SFTP is mostly serous, and the cytological results of examination of the fluid are negative. Fluid in the pleural cavity is more often found in patients with malignant tumors, which was also observed in the group of our patients - 2 (40\%) with malignant SFTP [3, 4].

Chest X-rays usually show a well-demarcated, round, oval, or lobular tumor. The average size of the mass is often quite large (8.5 to $10 \mathrm{~cm}$ ). Computerized tomography (CT) scan usually reveals a sharply defined, homogeneous soft mass adjacent to different areas of the pleura (Fig. 5). Sometimes, tumor calcification can also be observed [5, 10]. There are many reports on the use of positron emission tomography (PET) in patients with this type of cancer. Positron emission tomography scanning may be useful in predicting malignancy in cases of suspected malignant SFTP [15].

The treatment of choice for SFTP is surgery with tumor resection. Large tumors are treated via anterolateral thoracotomy. Other lesions can be removed by VATS. In our department, 6 patients (33\%) were treated with this method. One case required conversion to thoracotomy due to the location and dissection of the tumor. In all these patients, benign SFTP were revealed.

Negative resection margins constitute an important factor for further local recurrence. In our material, recurrence was observed even in cases of pedunculated tumors. Tumors originating from the parietal pleura are more challenging to resect due to the difficulty in obtaining a clear margin along the chest wall. Smaller tumors that are clinically and radiologically benign must be removed extrapleurally and sent for intraoperative analysis. Patients with 

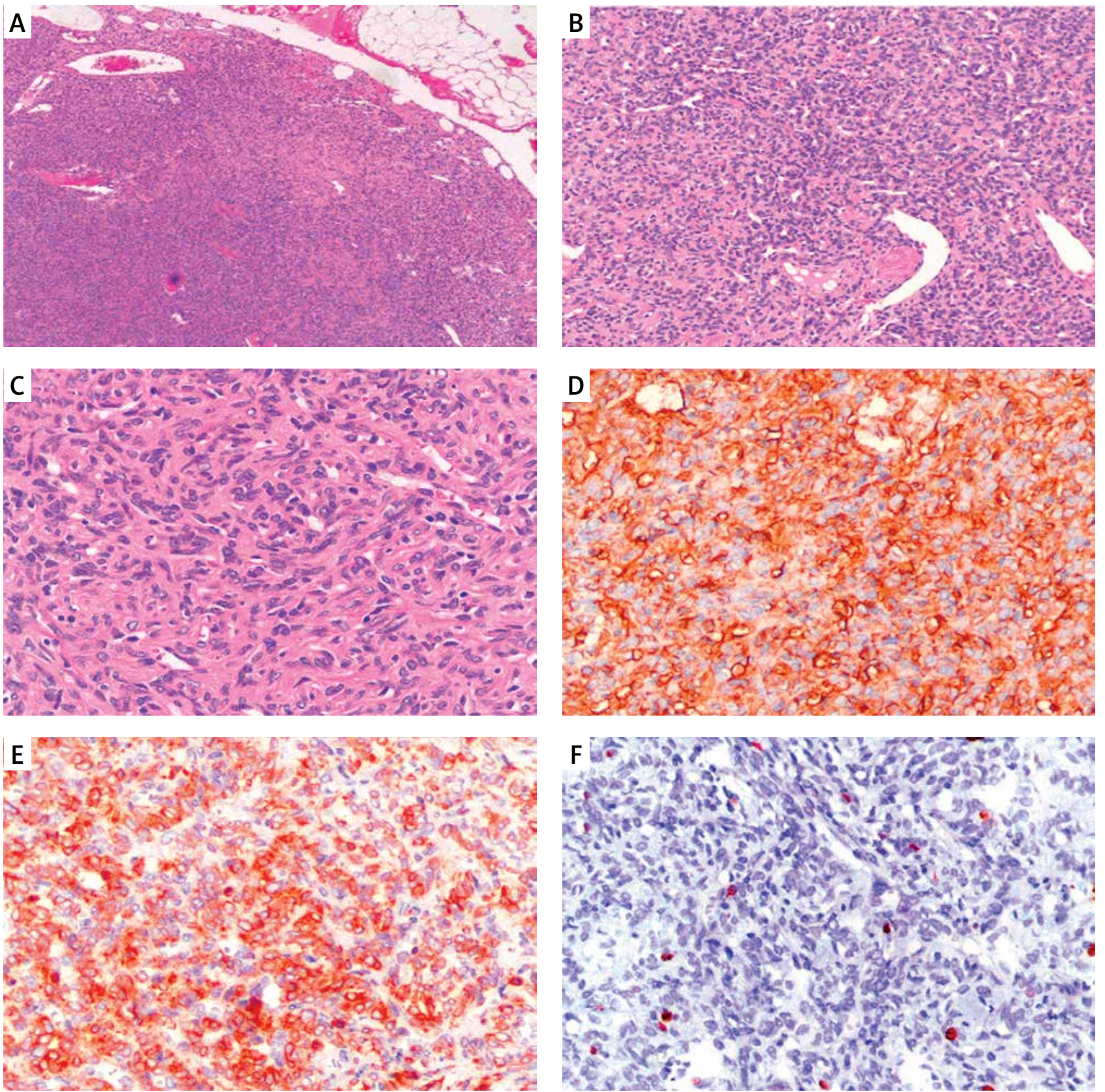

Fig. 3. A benign solitary fibrous tumor of the pleura. A) Well-demarcated tumor, lack of invasion of neighboring tissues (H\&E X40). B) Cell block showing a hemangiopericytomatous pattern (x100). C) Tumor consisting of small fibroblast-like cells without atypia, with a regular shape, oval and somewhat spindly, distributed between collagen fibers (x200). D) Immunohistochemical staining strongly positive for CD34 and vimentin (x100). E) Positive staining for Bcl-2 was observed in the cytoplasm of cells (x200). F) A low proliferative index Ki-67 (nuclear staining) of less than $1 \%$ of the cells. Ki-67 (Mib-1) (x100)

malignant tumors or tumors invading adjacent structures should undergo en-bloc resection with wide margins of adjacent tissues $[3,4,15,16]$.

\section{Conclusions}

Almost $80 \%$ of SFTP are benign, and more than $50 \%$ of their course is asymptomatic.

Obtaining histopathological diagnosis before surgery is difficult. Aspiration biopsy has low diagnostic sensitivity, and removing the tumor surgically is often the only way to establish the diagnosis.
The treatment consists in complete resection with negative margins in adjacent tissue. Benign and small tumors can be removed by VATS.

Determination of histological and immunohistochemical criteria is necessary to determine the nature of the SFTP.

Long-term postoperative follow-up should be mandatory in all cases because of the possibility of tumor recurrence.

\section{Disclosure}

Authors report no conflict of interest. 

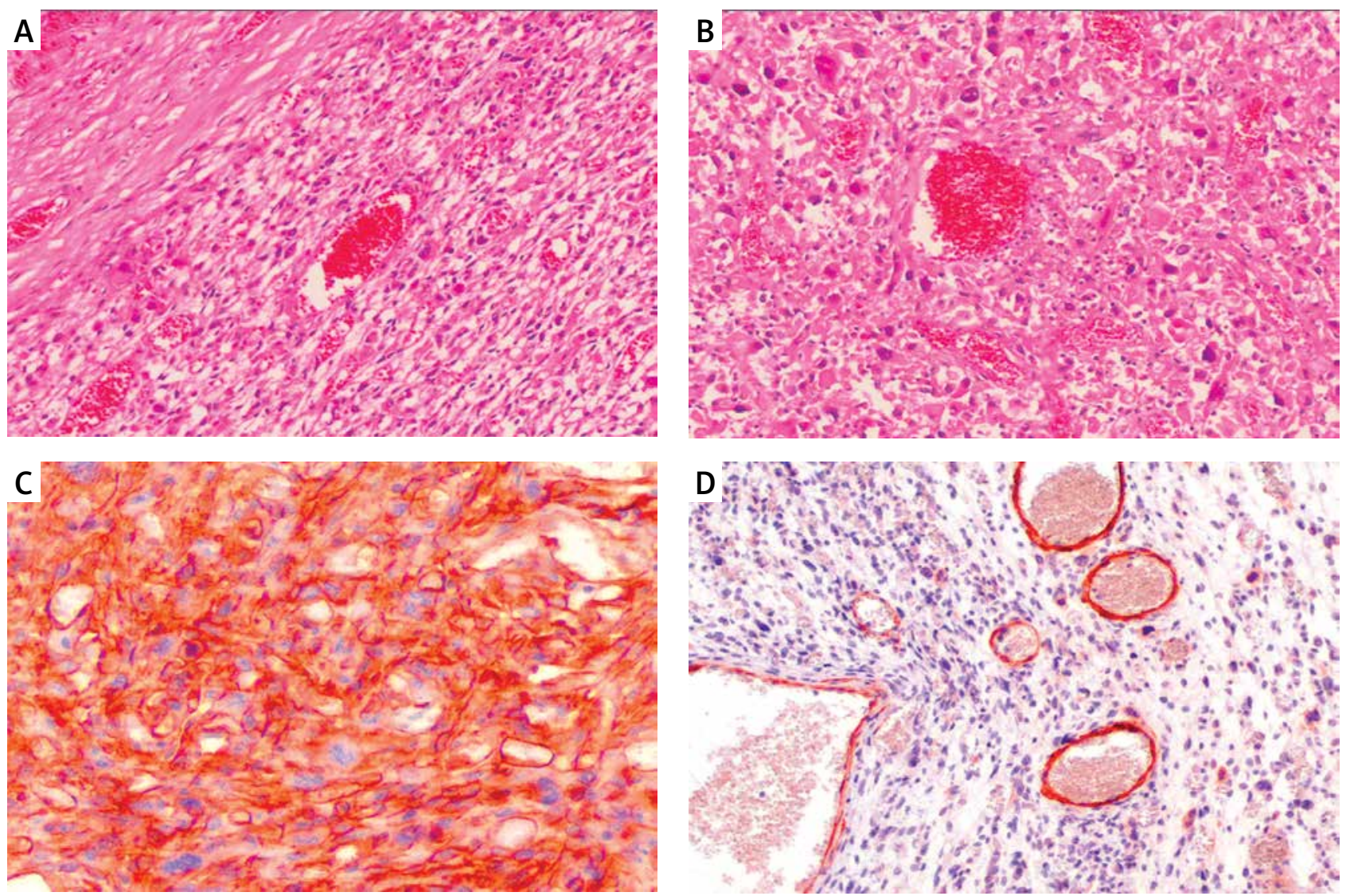

Fig. 4. A malignant solitary fibrous tumor. A) The tumor is surrounded by a fibrous capsule, infiltrating the adjacent tissue (H\&E x100). B) Cells in systems similar to those of a benign tumor; considerable cellular atypia and pleomorphism (x200). C) The malignant neoplasm shows the same immunophenotype as its benign counterpart; strong membrane expression and anti-CD34 antibodies on the tumor cells (x200). D) Several vessels with smooth muscle actin expression; the cells of the tumor are negative (SMA, x100)

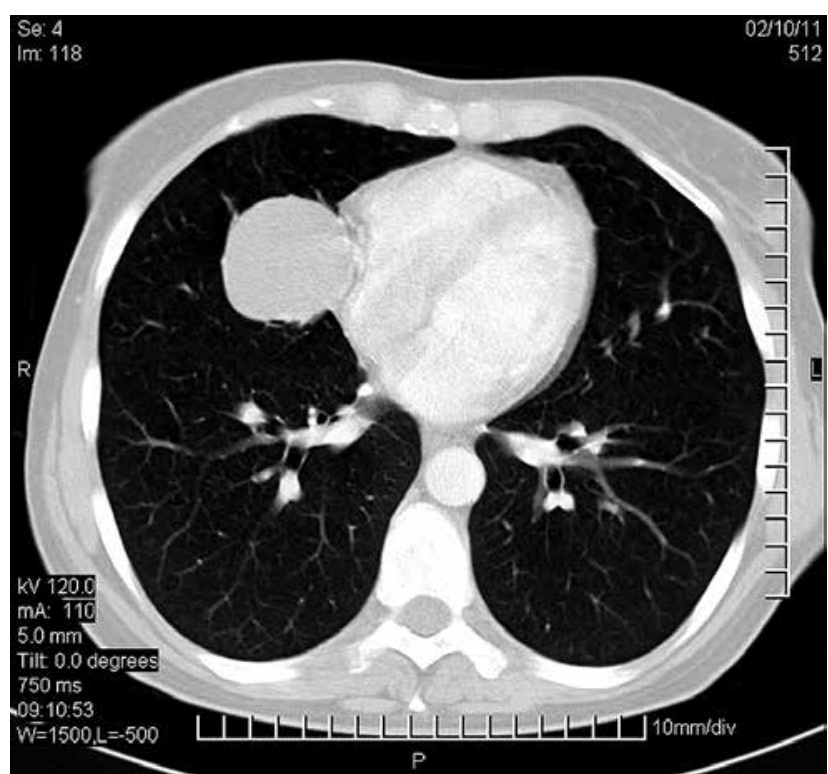

Fig. 5. Chest computerized tomography (CT) scan. A benign variant of solitary fibrous tumors of the pleura. Non-pedunculated tumor originating from the pulmonary pleura compressing the pericardium

\section{References}

1. De Perrot M, Kurt AM, Robert JH, Borisch B, Spiliopoulos A. Clinical behavior of solitary fibrous tumors of the pleura. Ann Thorac Surg 1999; 67: 14561459

2. De Perrot M, Fischer S, Bründler MA, Sekine $\mathrm{Y}$, Keshavjee S. Solitary fibrous tumors of the pleura. Ann Thorac Surg 2002; 74: 285-293.

3. Robinson LA. Solitary fibrous tumor of the pleura. Cancer Control 2006; 13: 264-269.

4. Abu Arab W. Solitary fibrous tumours of the pleura. Eur J Cardiothroac Surg 2012; 41: 587-597.

5. Briselli M, Mark EJ, Dickersin GR. Solitary fibrous tumors of the pleura: eight new cases and review of 360 cases in the literature. Cancer 1981; 47: 26782689.

6. Sung HS, Chang J-W, Kim J, Lee KS, Han J, Park S. Solitary fibrous tumors of the pleura: surgical outcome and clinical course. Ann Thorac Surg 2005; 79: 303-307.

7. Al-Azzi M, Thurlow NP, Corrin B. Pleural mesothelioma of connective tissue type, localized fibrous tumor of the pleura, and reactive submesothelial hyperplasia: an immunohistochemical comparison. J Pathol 1989; 158: 41-44.

8. Wagner E. Das tuberkelahnliche Lymphadenom (Der cytogene oder reticulirte Tuberkel). Arch Heilk (Leipzig) 1870; 11: 497.

9. Klemperer P, Rabin CB. Primary neoplasm of the pleura: a report offive cases. Arch Pathol 1931; 11: 385-412.

10. England DM, Hochholzer L, McCarthy MJ. Localized benign and malignant fibrous tumors of the pleura: a clinicopathologic review of 223 cases. Am J Surg Pathol 1989; 13: 640-658.

11. Yokoi T, Tsuzuki T, Yatabe Y, Suzuki M, Kurumaya H, Koshikawa T, Kuhara H, Kuroda M, Nakamura N, Nakatani Y, Kakudo K. Solitary fibrous tumour: sig- 
nificance of p53 and CD34 immunoreactivity in its malignant transformation. Histopathology 1998; 32: 423-432.

12. Lahon B, Mercier O, Fadel E, Ghigna MR, Petkova B, Mussot S, Fabre D, Le Chevalier T, Dartevelle P. Solitary fibrous tumor of the pleura: outcomes of 157 complete resections in a single center. Ann Thorac Surg 2012; 94: 394-400.

13. Martini N, McCrmack PM, Bains MS, Kaiser LR, Burt ME, Hilaris BS. Pleural mesothelioma. Ann Thorac Surg 1987; 43: 113-120.

14. Okike N, Bernatz PE, Woolner LB. Localized mesothelioma of the pleura: benign and malignant variants. J Thorac Cardiovasc Surg 1978; 75: 363-372.

15. Wright C, Mark E. Benign Tumors of the Pleura. Pleural Disease. Second Edition, 2009; 26:448-466.

16. Cardillo G, Facciolo F, Cavazzana AO, Capece G, Gasparri R, Martelli M. Localized (solitary) fibrous tumors of the pleura: an analysis of 55 patients. Ann Thorac Surg 2000; 70: 1808-1812.
17. Jha V, Gil J, Teirstien AS. Familial solitary fibrous tumor of the pleura: a case report. Chest 2005; 127: 1852-1854.

18. Miettinen MM, El-Rifai W, Sarlomo-Rikala M, Andersson LC, Knuutila S. Tumor size-related DNA copy number changes occur in solitary fibrous tumors but not in hemangiopericytomas. Mod Pathol 1997; 10: 194-200.

19. Magdeleinat P, Alifano M, Petino A, Le Rochais JP, Dulmet E, Galateau F, Icard P, Regnard JF. Solitary fibrous tumors of the pleura: clinical characteristics, surgical treatment and outcome. Eur J Cardio Thorac Surg 2002; 21: 1087-1093.

20. Meng W, Zhu HH, Li H, Wang G, Wei D, Feng X. Solitary fibrous tumors of the pleura with Doege-Potter syndrome: a case report and three-decade review of the literature. BMC Res Notes 2014; 7: 515 